Article

\title{
A Geospatial Approach for Prioritizing Wind Farm Development in Northeast Nebraska, USA
}

\section{Adam Miller and Ruopu Li *}

School of Natural Resources, University of Nebraska-Lincoln, 324 Hardin Hall, Lincoln, NE 68583, USA; E-Mail: amill_533@live.com

* Author to whom correspondence should be addressed; E-Mail: rli3@unl.edu; Tel.: +1-402-471-0378; Fax: +1-402-472-2946.

Received: 6 March 2014; in revised form: 2 July 2014 / Accepted: 9 July 2014 / Published: 17 July 2014

\begin{abstract}
Being cleaner and climate friendly, wind energy has been increasingly utilized to meet the ever-growing global energy demands. In the State of Nebraska, USA, a wide gap exists between wind resource and actual energy production, and it is imperative to expand the wind energy development. Because of the formidable costs associated with wind energy development, the locations for new wind turbines need to be carefully selected to provide the greatest benefit for a given investment. Geographic Information Systems (GIS) have been widely used to identify the suitable wind farm locations. In this study, a GIS-based multi-criteria approach was developed to identify the areas that are best suited to wind energy development in Northeast Nebraska, USA. Seven criteria were adopted in this method, including distance to roads, closeness to transmission lines, population density, wind potential, land use, distance to cities, slope and exclusionary areas. The suitability of wind farm development was modeled by a weighted overlay of geospatial layers corresponding to these criteria. The results indicate that the model is capable of identifying locations highly suited for wind farm development. The approach could help identify suitable wind farm locations in other areas with a similar geographic background.
\end{abstract}

Keywords: wind energy; GIS; multi-criteria; wind farm; Nebraska 


\section{Introduction}

Renewable energy production has gained popularity worldwide due to the rapid depletion of fossil fuels and a global effort to reduce carbon emissions to mitigate climate change [1]. As an important type of renewable energy, wind energy is growing rapidly in use across the world [2]. Compared with conventional fossil fuels [3], wind energy can be generated and used at the local level with virtually no transportation cost. It is estimated that approximately 10 million megawatts (MW) of wind energy is available to use on the earth at all times [2]. As technology continues to advance, wind energy is expected to be further expanded with better efficiency to meet growing energy needs [4].

The U.S. state of Nebraska has great potential for the production of wind energy, ranking fourth among the 50 U.S. states in wind energy resources. However, it only ranked 24th regarding the actual wind energy production [5]. As of 30 September 2013, Nebraska has 260 wind turbines with a production capacity of approximately $460 \mathrm{MW}$, which is much lower than its potential capacity of $7800 \mathrm{MW}$ [5]. Many locations in the state have good and excellent wind potential as rated by the National Renewable Energy Laboratory (NREL) [6]. The wide gap between wind resource potential and actual energy production indicates great potential for the expansion of wind energy development in the state (Figure 1). Therefore, the state of Nebraska has considerable potential for further wind energy development.

Figure 1. A comparison of installed capacity and potential wind energy in the State of Nebraska, U.S., as of 30 September 2013.

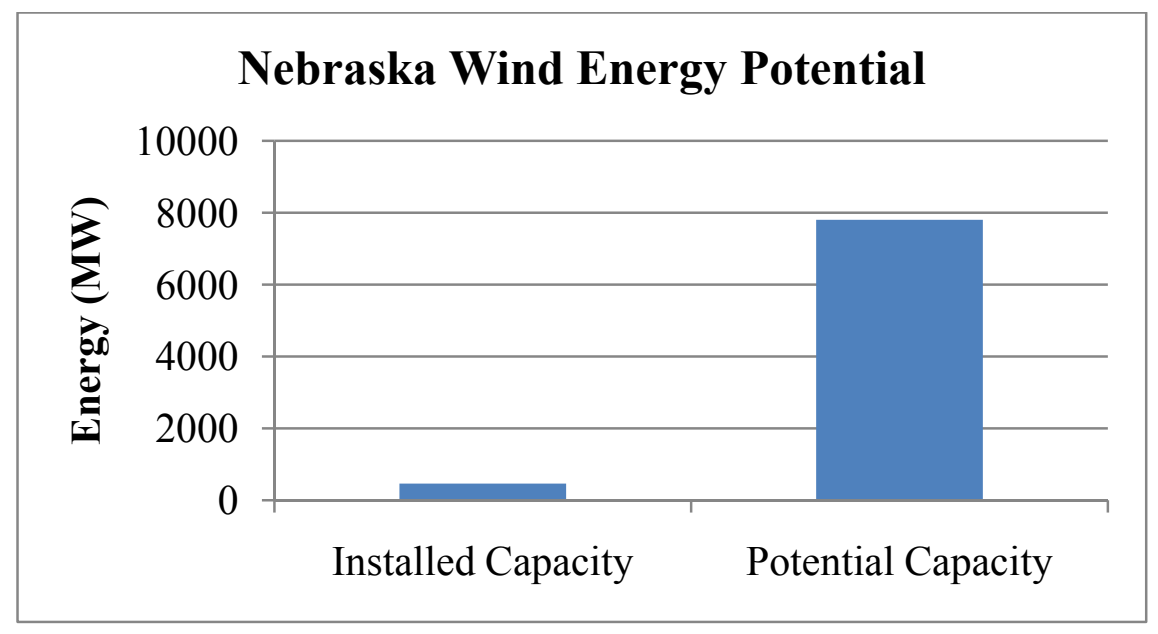

One of the major technical challenges to wind energy development is to locate the areas with high suitability for placing wind farms [7]. Wind farms generally require large initial investments; for example, a wind farm built in Ainsworth, Nebraska in 2005 cost around 81 million U.S. dollars [8]. Thus, finding suitable locations for wind farm installation is critical for the economic success of wind farm operation. In the past few decades, Geographic Information Systems (GIS) have been widely used to assist in searching for suitable sites for wind farms $[7,9,10]$. GIS provides the functionalities of integrating a large spectrum of geospatial information into the decision-making of wind energy development. For example, Baban and Parry selected a total of 14 criteria (e.g., slope, historic site, land use) based on information collected from questionnaires and literature review and used a 
weighted overlay analysis in GIS to determine potential suitable locations of wind farms in the United Kingdom [9]. Similarly, Janke used multi-criteria GIS modeling techniques to find potential locations for wind farms in the State of Colorado, U.S. [11]. Factors, such as wind potential, distance to cities and roads and population density, were garnered from available geospatial databases, converted to a raster data structure and overlaid to produce a wind development suitability map for northeastern Colorado. In addition to the aforementioned factors, a study conducted in the State of New York, U.S. added new ecological and economic criteria, such as the avoidance of avian impacts and economic costs to the wind development model [10]. Van Hoesen and Letendre identified the viewshed as a critical factor to quantify the visual impact of wind turbines in the State of Vermont, U.S. [12]. Rodman and Meentemeyer utilized a rules-based GIS modeling approach to assess the suitability of wind farms in Northern California, U.S., in which factors were grouped into three categories (i.e., physical, environmental and socio-economic) [7]. A group of technical, economic and policy factors were incorporated into a GIS tool to define the locations for wind farm sites in Iowa, U.S. [13]. A similar approach was adopted to locate available areas for installing wind turbines in southwestern Taiwan [14]. The study areas, modeling approaches and modeling factors used in the above and other studies are summarized in Table 1. Almost all of them used the same GIS-based modeling approach: multi-criteria analysis.

Table 1. Study areas, modeling approaches and factors adopted by studies on land suitability for wind energy development.

\begin{tabular}{|c|c|c|c|}
\hline Study/Research & Study Area & $\begin{array}{l}\text { Modeling } \\
\text { Approach }\end{array}$ & Factors \\
\hline Aydin et al., 2010 [1] & Western Turkey & $\begin{array}{l}\text { Multi-criteria } \\
\text { decision-making } \\
\text { with fuzzy set } \\
\text { theory }\end{array}$ & $\begin{array}{l}\text { Distance to natural reserves, distance to large cities, distance from towns, distance } \\
\text { from airports, noise, distance from lakes and wetlands, wind power }\end{array}$ \\
\hline Janke, 2010 [11] & Colorado, U.S. & $\begin{array}{l}\text { Multi-criteria } \\
\text { analysis }\end{array}$ & $\begin{array}{l}\text { Wind potential, distance to transmission lines, distance to cities, population density, } \\
\text { distance to roads, land cover, federal lands }\end{array}$ \\
\hline $\begin{array}{l}\text { Rodman and } \\
\text { Meentemeyer, } \\
2006[7]\end{array}$ & $\begin{array}{l}\text { Northern } \\
\text { California, U.S. }\end{array}$ & $\begin{array}{l}\text { Rule-based } \\
\text { spatial analysis }\end{array}$ & $\begin{array}{l}\text { Physical criteria: wind speed, forest density, valley slope and distance to ridge; } \\
\text { Environmental criteria: vegetation, endangered plant species and wetlands; Human } \\
\text { impact criteria: urban areas and recreation areas }\end{array}$ \\
\hline $\begin{array}{l}\text { Van Haaren and } \\
\text { Fthenakis, } 2011[10]\end{array}$ & New York, U.S. & $\begin{array}{l}\text { Multi-stage } \\
\text { multi-criteria } \\
\text { analysis }\end{array}$ & $\begin{array}{l}\text { Economic evaluation: distance to transmission grid, distance to roads, land } \\
\text { clearing costs, wind resources; Bird impact evaluation; Excluded locations: urban } \\
\text { areas, federal lands, reservations, roads, lakes, steep slopes, karst areas; Planning } \\
\text { criteria: noise }\end{array}$ \\
\hline $\begin{array}{l}\text { Van Hoesen and } \\
\text { Letendre, } 2010[12]\end{array}$ & $\begin{array}{l}\text { Poultney } \\
\text { Valley, } \\
\text { Vermont, U.S. }\end{array}$ & $\begin{array}{c}\text { GIS-based } \\
\text { overlay analysis }\end{array}$ & $\begin{array}{l}\text { Wind potential, viewshed for visual impact including heights of canopy, } \\
\text { slopes and elevation }\end{array}$ \\
\hline
\end{tabular}

With the aforementioned wide gap between wind energy potential and energy development in Nebraska, it is advantageous to expand the production of renewable energy in the near future. However, no modeling study has been found to specifically guide the search for potential wind farm locations in Nebraska. The objective of this research paper is to develop a modeling framework to determine suitable locations for wind farm development in Nebraska considering its unique physical 
and socio-economic landscape. It is expected that this paper can lead to improved understanding of the wind farm development potential in a wind-rich state whose resource is still under development. The modeling approach was tested in a study area located in northeast Nebraska.

\section{Methods}

\subsection{Study Area}

Two counties, Knox and Pierce, in northeast Nebraska (Figure 1) were selected as the study area. The average precipitation in this region is around $63 \mathrm{~cm}$ per year. The maximum and minimum temperature averages are around $16{ }^{\circ} \mathrm{C}$ and $2{ }^{\circ} \mathrm{C}$, respectively [15]. The average wind speed ranges from 8 to $9.6 \mathrm{~km} /$ hour [15]. Based on the Wind Energy Potential Map developed by NREL [6], both counties have extensive areas with a good wind potential rating. In the context of the U.S. Midwest agricultural landscape, the study area features relatively low population density and flat terrain. There are two existing wind farms in the study area, one near Bloomfield and one near Crofton, both of which are located in Knox County [8] (Figure 2).

Figure 2. Location map of study area, Knox and Pierce Counties, Nebraska.

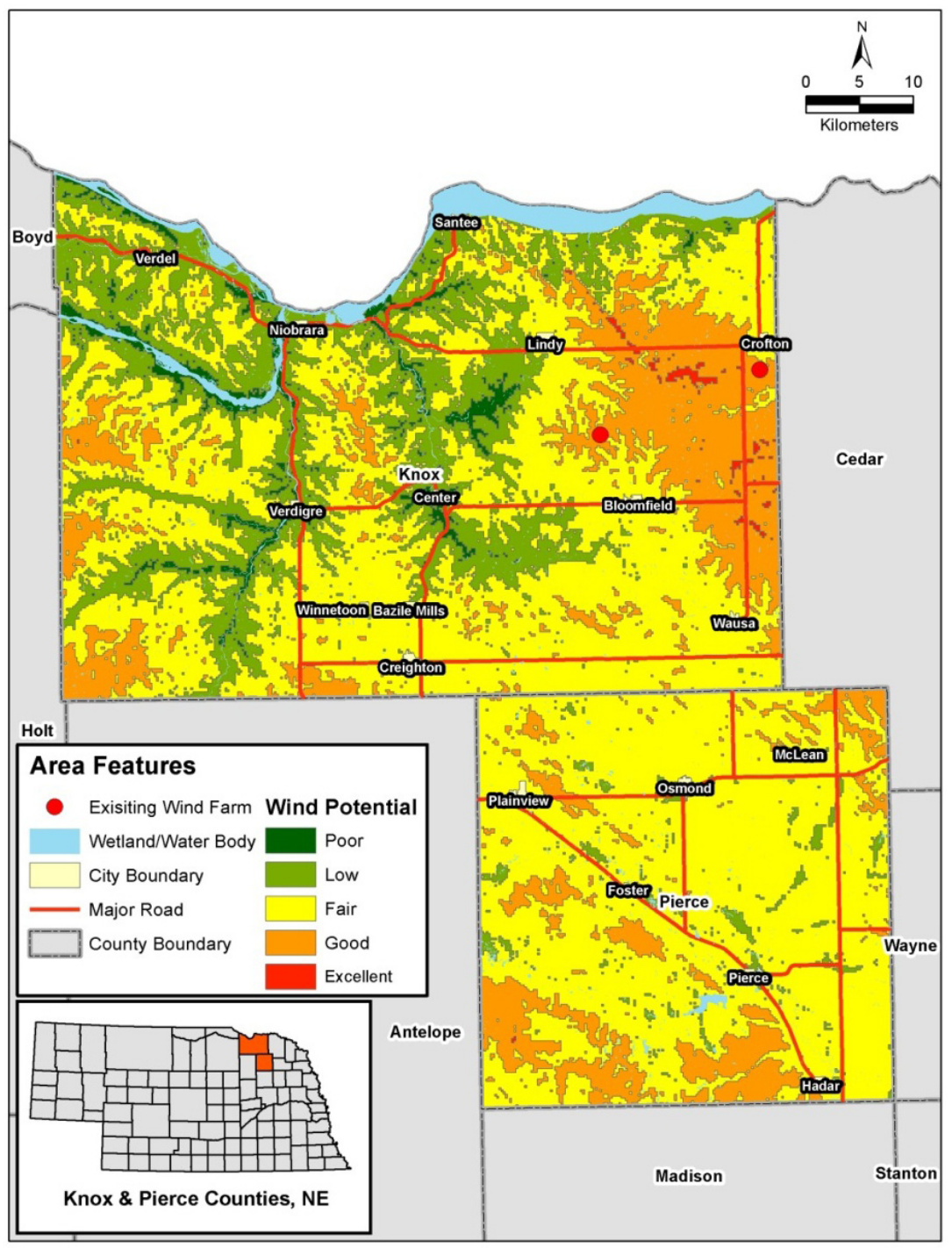




\subsection{Selection of Model Factors}

A suite of 7 criteria were chosen for modeling the suitability of wind farm locations, including wind energy potential, land use, population density, distance to major roads, slope, distance to transmission lines and exclusionary areas (i.e., areas where cities and towns, wetlands, airports and roads are located). The criteria selection started with a comprehensive literature review and was narrowed down to those criteria deemed as relevant and critical to the suitability of a wind farm installation in Nebraska. All layers were projected into NAD 1983 UTM Zone 14 and converted into raster data structure. All of the raster datasets were resampled to a common cell size $(200 \mathrm{~m})$, which was based on the coarsest cell size of all source datasets. Table 2 shows the justification, data sources and data structures of the criteria used to model wind farm suitability.

Wind speed above certain levels is essential to make wind energy production possible [9]. The wind potential data was produced as five rating classes (from poor to excellent) by NREL based on wind speed data at $50 \mathrm{~m}$ above the ground [16].

Table 2. Criteria and data sources used to model wind farm suitability.

\begin{tabular}{|c|c|c|c|c|}
\hline Criteria & Data Sources & Reasons for Selection & $\begin{array}{c}\text { Original Data } \\
\text { Structure }\end{array}$ & $\begin{array}{c}\text { Original } \\
\text { Resolution/Feature type }\end{array}$ \\
\hline Slope & USGS DEMs $^{1}[17]$ & $\begin{array}{l}\text { Slope affects the ease of construction and } \\
\text { maintenance }[18]\end{array}$ & Raster & $30 \mathrm{~m}$ \\
\hline $\begin{array}{l}\text { Wind Energy } \\
\text { Potential }\end{array}$ & $\begin{array}{l}\text { NREL Wind Energy } \\
\text { Potential Map [19] }\end{array}$ & $\begin{array}{l}\text { Wind potential is essential for wind } \\
\text { energy production [9] }\end{array}$ & Raster & $200 \mathrm{~m}$ \\
\hline Land Use & $\begin{array}{c}2005 \text { Nebraska Land } \\
\text { Use Dataset [20] }\end{array}$ & $\begin{array}{l}\text { Land use is a criterion representing } \\
\text { the environmental impacts of the } \\
\text { wind farms [7] }\end{array}$ & Raster & $30 \mathrm{~m}$ \\
\hline $\begin{array}{l}\text { Population } \\
\text { Density }\end{array}$ & $\begin{array}{l}\text { U.S. Census Bureau } \\
\qquad \text { TIGER }^{2}[21]\end{array}$ & $\begin{array}{l}\text { Public concerns regarding its visual and } \\
\text { noise impacts [7] }\end{array}$ & Vector & Polygon \\
\hline $\begin{array}{c}\text { Distance to } \\
\text { Transmission } \\
\text { Lines }\end{array}$ & $\begin{array}{l}\text { U.S. Census Bureau } \\
\text { TIGER [21] }\end{array}$ & $\begin{array}{l}\text { Reducing the cost of building new } \\
\text { transmission lines [9] }\end{array}$ & Vector & Polyline \\
\hline $\begin{array}{l}\text { Distance to } \\
\text { Roads }\end{array}$ & $\begin{array}{l}\text { U.S. Census Bureau } \\
\text { TIGER [21] }\end{array}$ & $\begin{array}{l}\text { Allowing for better access for } \\
\text { construction and maintenance [9] }\end{array}$ & Vector & Polyline \\
\hline $\begin{array}{l}\text { Exclusionary } \\
\text { Areas (towns) }\end{array}$ & $\begin{array}{l}\text { U.S. Census Bureau } \\
\text { TIGER [21] }\end{array}$ & $\begin{array}{l}\text { Conflicting land use preoccupied by } \\
\text { human infrastructure }\end{array}$ & Vector & Polygon \\
\hline $\begin{array}{c}\text { Exclusionary } \\
\text { Areas (wetlands) }\end{array}$ & $\begin{array}{l}\text { National Wetlands } \\
\text { Inventory [22] }\end{array}$ & Avoiding ecological sensitive areas [10] & Vector & Polygon \\
\hline $\begin{array}{c}\text { Exclusionary } \\
\text { Areas (airports) }\end{array}$ & $\begin{array}{l}\text { U.S. Census Bureau } \\
\text { TIGER [21] }\end{array}$ & $\begin{array}{c}\text { Conflicting land use preoccupied by } \\
\text { human infrastructure }\end{array}$ & Vector & Polygon \\
\hline $\begin{array}{l}\text { Exclusionary } \\
\text { Areas } \\
\text { (Railroads) }\end{array}$ & $\begin{array}{l}\text { U.S. Census Bureau } \\
\text { TIGER [21] }\end{array}$ & Avoiding areas on the railroads [18] & Vector & Polyline \\
\hline
\end{tabular}

${ }^{1}$ USGS DEMs, the acronym of U.S. Geological Survey Digital Elevation Models;

${ }^{2}$ TIGER, the acronym of Topologically Integrated Geographic Encoding and Referencing. 
Land use is a criterion representing the environmental impacts of the wind farms [7]. Wind turbines should be installed on the land with the lowest disruption to the existing land use. The land use data was derived from the 2005 Nebraska Land Use Dataset, which was developed by The Center for Advanced Land Management Information Technologies (CALMIT), University of Nebraska-Lincoln. The original dataset has 25 different classes, among which agricultural and barren lands were ranked as high suitability, shrub land and woodlands as low suitability and wetlands and urban areas unsuitable.

The wind turbine placement is susceptible to public resistance, due to the public concerns regarding its visual and noise impacts [7]. Thus, ideally, wind farms should be placed in the less densely populated areas. The data used for population density was derived from the Topologically Integrated Geographic Encoding and Referencing (TIGER) dataset by the U.S. Census Bureau.

Wind turbines should be placed near existing transmission lines and roads to help reduce the cost associated with wind farm construction and maintenance [9]. Buffers were placed around major roads of $10,000 \mathrm{~m}$ and transmission lines of $20,000 \mathrm{~m}$, with suitability scores assigned in accordance to the proximity. The datasets of roads and transmission lines was derived from the TIGER/Line Shapefiles.

Topography with steep slopes is generally regarded as less suitable, due to the extra construction and maintenance costs [18]. The slope layer was derived from the 30-m Digital Elevation Models (DEMs) produced by U.S. Geological Survey (USGS), and any location with a slope less than 7\% was considered most suitable [7].

Lastly, wind turbines should be excluded from certain areas preoccupied by human infrastructure and ecologically sensitive areas, such as urban areas, roads, railroads, airports [18] and wetlands [10]. The boundaries of city, roads, railroads and airport layers were all downloaded from the U.S. Census Bureau and extracted from the TIGER dataset. Areas within $100 \mathrm{~m}$ [9] of roads and railroads were considered unsuitable, which were determined using buffer analyses. Areas within a 1600-m buffer around cities and towns were considered unsuitable [18]. The wetlands dataset was derived from the National Wetlands Inventory (NWI) by the U.S. Fish and Wildlife Service.

\subsection{Modeling Procedure}

In accordance with common practice in wind energy potential modeling (as seen in Table 1), the multi-criteria analysis was selected for modeling, starting with data conversion and reclassification. All of the selected criteria were first converted into the raster data structure with a resolution of $200 \mathrm{~m}$ and then reclassified into ordinal suitability scores of $0-4$, with 4 being the most suitable and 0 unsuitable. The score rating scheme was developed based on a review of related published studies (Table 3). Slope was reclassified into four categories. Any area with slope less than $7 \%$ was regarded as highly suitable and assigned the highest rating score (4), while areas with a slope greater than $40 \%$ were assigned the lowest score (0) [7]. The wind potential was reclassified in reference to the NREL wind power classes, and areas with wind speeds above $7.5 \mathrm{~m} / \mathrm{s}$ were considered most suitable and less than $5.6 \mathrm{~m} / \mathrm{s}$ unsuitable. Agriculture and barren lands were assigned the highest score of 4; grasslands were given 3, shrub lands 2, forest/woodland 1 and wetlands and urban areas 0 [18]. Population density was divided into classes where lower density received a higher score and vice versa [7]. Suitability scores generally increased with proximity to the transmission lines and major roads. However, locations over 20,000 $\mathrm{m}$ [11] and 10,000 $\mathrm{m}$ [7] away from the transmission lines and major 
roads, respectively, were rated as unsuitable. The rating scores for each layer's reclassification map are shown in Figure 3.

Table 3. Rating scheme for multiple modeling criteria.

\begin{tabular}{|c|c|c|c|c|c|c|}
\hline $\begin{array}{l}\text { Suitability } \\
\text { Score }\end{array}$ & $\begin{array}{c}\text { Slope } \\
\text { (Degrees) }\end{array}$ & $\begin{array}{c}\text { NREL } \\
\text { WPC }(50 \mathrm{~m}) \\
\text { Speed }(\mathrm{m} / \mathrm{s}) \\
\end{array}$ & Land Use & $\begin{array}{c}\text { Population } \\
\text { Density } \\
\left(\text { person } / \mathbf{m i}^{2}\right) \\
\end{array}$ & $\begin{array}{c}\text { Distance to } \\
\text { Transmission } \\
\text { Line (m) } \\
\end{array}$ & $\begin{array}{l}\text { Distance } \\
\text { to Major } \\
\text { Road (m) }\end{array}$ \\
\hline High (4) & {$[0,7]$} & $>7.5$ & Agriculture/Barren & $(0,25]$ & $(0,5000]$ & $(0,1000]$ \\
\hline Medium (3) & $(7,16]$ & $(7,7.5]$ & Grassland & $(25,50]$ & $(5000,10,000]$ & $\begin{array}{l}(1000 \\
2500]\end{array}$ \\
\hline Low (2) & $(16,30]$ & $(6.4,7]$ & Shrub land & $(50,100]$ & $\begin{array}{c}(10,000 \\
15,000]\end{array}$ & $\begin{array}{l}(2500, \\
5,000]\end{array}$ \\
\hline Lowest (1) & $(30,40]$ & $(5.6,6.4]$ & Forest/Woodland & $(100,150]$ & $\begin{array}{l}(15,000 \\
20,000]\end{array}$ & $\begin{array}{c}(5000, \\
10,000]\end{array}$ \\
\hline Unsuitable (0) & $>40$ & $(0,5.6]$ & $\begin{array}{c}\text { Wetlands/Urban/ } \\
\text { Water }\end{array}$ & $>150$ & $>20,000$ & $>10,000$ \\
\hline
\end{tabular}

Figure 3. Spatial patterns of suitability scores for each criterion (exclusionary area excluded).

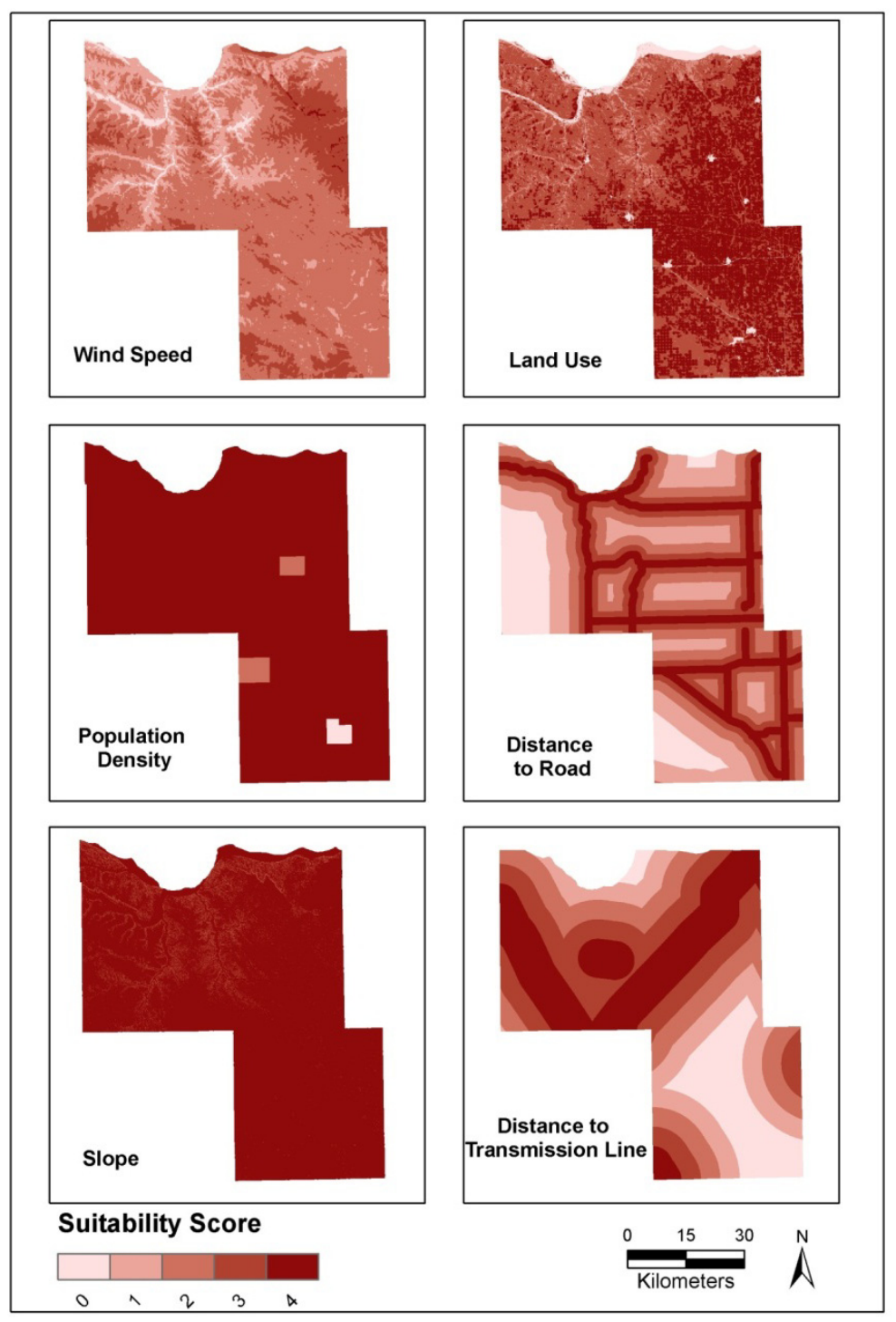


Table 4. Weights assigned to each modeling criterion.

\begin{tabular}{cc}
\hline Layer & Assigned Weight \\
\hline Wind energy potential & 3 \\
Slope & 2 \\
Land use & 2 \\
Distance to transmission lines & 2 \\
Distance to roads & 2 \\
Population density & 1 \\
\hline
\end{tabular}

Figure 4. Flowchart for modeling suitability of wind farm development.

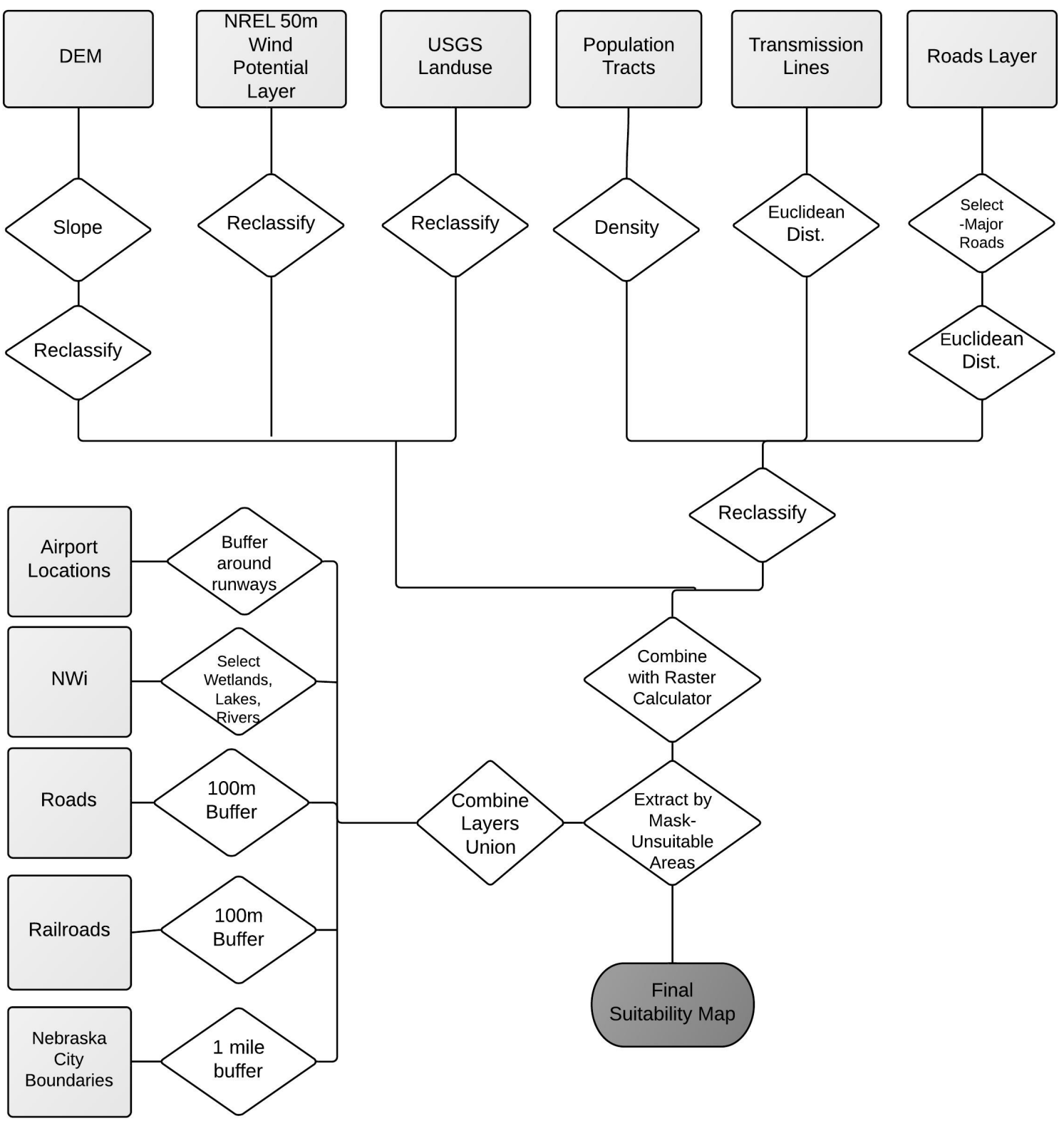

Weights were also assigned to each layer to reflect the relative importance of each factor in modeling preferential wind farm locations. The values of the weights range between 1 and 3 , with 3 representing the most important criteria (Table 4). The determination was based on a review of related literature [11] and an evaluation of the relative importance of different criteria for the study area. Wind 
potential was rated as the most important criteria affecting wind energy development. Slope, land use, distance to transmission lines and roads were all assigned a weight of two. Population density was assigned a value of one, because areas with a high population density coincide with the exclusionary areas (cities and towns).

The different geospatial layers for the modeling criteria were combined using the weighted overlay in ArcGIS (version 10.1). The detailed modeling steps are shown in the flowchart as shown in Figure 4. The final suitability scores in the study area were determined by reclassifying the scores derived from the weighted overlay into four classes based on the Jenks natural breaks method. The Jenks natural breaks method was selected, as this classification procedure seeks to minimize the variation within classes statistically [23]. The areas corresponding to the exclusionary areas were rated as "not suitable".

\section{Results and Discussions}

Figure 5 shows the final suitability map for the wind energy development in the study area. The map has five categories of suitability scores: not suitable, very low, low, medium and high. Approximately $33.06 \%$ of the land area in the study area fell into the high suitability category. The areas with high suitability were dominantly located in eastern and south central Knox County, as well as northeast Pierce County. There are two existing wind farms, the Elkhorn Ridge Wind Farm near Bloomfield, NE, and the Crofton Bluffs Wind Farm near Crofton, NE, both of which fall within areas modeled as high suitability [8].

According to the wind farm suitability map (Figure 5), many locations within these counties have high suitability scores, indicating substantial potential for more wind farm placement in this region. The modeled suitability for wind farm development can be tested by a comparison with existing wind farms in this area. Currently, there are only two wind farm sites, Crofton Bluffs Wind Farm and Elkhorn Ridge Wind Farm, located in south-central Knox County and northeast Pierce County, respectively. Both sites coincide with areas with high suitability scores for wind farm development, indicating that the model was fairly formulated and that the resulting map can be used to guide wind development in this region. State energy policy makers and energy planners may use the results to guide where future wind farms can be feasibly located.

In this study, a multi-criteria GIS-based modeling framework provides a means of determining the suitable sites for wind farm placement in a cost-effective manner. The criteria were selected from different data sources to reflect the engineering, socio-economic and environmental considerations. For example, wind energy potential and slope are related to the geographic conditions meeting the engineering-design requirements of wind farms; distance to transmission lines and roads are associated with the costs of wind energy development; and land use and population density affect public acceptance and environmental concerns. By mapping out these criteria separately (Figure 3), it is possible to identify the impact of each factor that either contributes to or opposes the placement of wind farms. The weighting and rating scheme was also carefully designed through a comprehensive literature review of related studies. Furthermore, the modeling framework could be potentially improved by including additional criteria, such as the demands of investors, utilities, governmental agencies and environmentalists [11] and visibility to human development or recreational areas [7]. More resources are needed to develop the geospatial layers for those criteria. 
Figure 5. Suitability map for wind farm development in Northeast Nebraska.

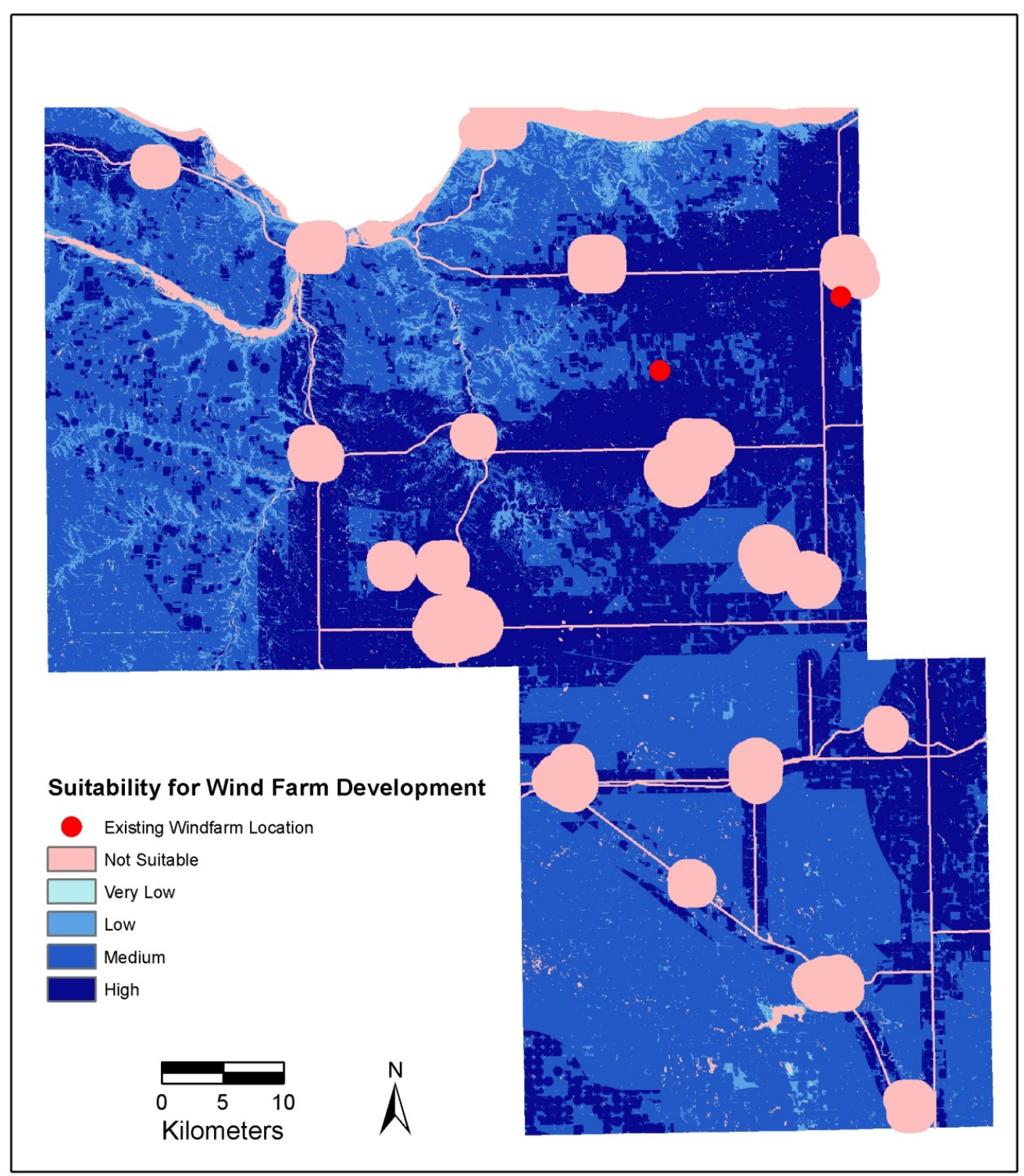

It is recognized that a few limitations exist in this study. First, the datasets used to model suitability came from sources with different resolutions and scales, and the associated uncertainties were inherent in the modeling. Second, the criteria were weighted and combined in a linear model. The weighting and rating scheme is subjective to uncertainty, although it was mainly derived based on other studies. In addition, distance to transmission lines was adopted as a simplified cost-related factor regardless of the capacity of transmission lines, the information of which was generally unavailable. Furthermore, it should also be noted that the modeled suitability should be interpreted as the "probability" of success in wind farm development. The suitability map can be used as a guidance to narrow down the search scope of new wind farm sites. However, field-level surveys or field visits [24] should also be incorporated into the final decision-making process before any large investment in construction. The application of the mapping results still needs to be validated with field measurements of wind speed and observation of any ecological variables, like sensitive habitats or migratory bird routes, that may exist in any given location [11]. 


\section{Conclusions}

Wind energy production has gained increasing popularity as a cleaner alternative to fossil fuels. The gap between wind resource availability and actual production clearly demonstrates the potential of further wind energy development in the State of Nebraska, U.S. GIS has been widely used as a cost-effective spatial decision support tool to select the best locations to place wind farms. In this study, a suite of physical and socio-economic factors were selected as criteria to analyze the suitable locations for wind farm development, including wind potential, land use, population density and distance to major roads, slope and transmission lines. It is also important to note that wind farms should exclude areas with dedicated municipal and ecological purposes, such as roads or near cities, wetlands and airports. Areas in the eastern and south-central portions of Knox County and northeast Pierce County were considered highly suitable for wind development. The appropriateness of the wind farm suitability map was tested by the fact that two existing wind farms are located in areas with high suitability. Although the suitability map was developed for two counties, the proposed method has potential to be applied to the rest of places in the state. The method illustrated in this study, if used with care, may be applicable to other regions of the world with the similar background.

\section{Author Contributions}

Both authors have equal contributions to the research and writings of the paper.

\section{Conflicts of Interest}

The authors declare no conflict of interest.

\section{References}

1. Aydin, N.Y.; Kentel, E.; Duzgun, S. GIS-based environmental assessment of wind energy systems for spatial planning: A case study from western Turkey. Renew. Sustain. Energy Rev. 2009, 14, 364-373.

2. Herbert, G.M.; Iniyan, S.; Sreevalsan, E.; Rajapandian, S. A review of wind energy technologies. Renew. Sustain. Energy Rev. 2007, 11, 1117-1145.

3. Delucchi, M.A.; Jacobson, M.Z. Meeting the world's energy needs entirely with wind, water, and solar power. Bull. Atomic Sci. 2013, 69, 30-40.

4. Wiser, R.; Bolinger, M. Annual Report on U.S. Wind Power Installation, Cost, and Performance Trends: 2007; Office of Energy Efficiency and Renewable Energy, US Department of Energy: Oak Ridge, TN, USA, 2008.

5. Natural Resources Defense Council. Renewable Energy for America-Nebraska. 2014. Available online: http://www.nrdc.org/energy/renewables/nebraska.asp (accessed on 3 February 2014).

6. US Department of Energy. Nebraska 50-meter Wind Map. 2014. Available online: http://www.windpoweringamerica.gov/maps_template.asp?stateab=ne (accessed on 1 March 2014).

7. Rodman, L.C.; Meentemeyer, R.K. A geographic analysis of wind turbine placement in Northern California. Energy Policy 2006, 34, 2137-2149. 
8. Nebraska Energy Association. Wind Energy Generation in Nebraska. 2014. Available online: http://www.neo.ne.gov/statshtml/89.htm (accessed on 3 February 2014).

9. Baban, S.M.J.; Parry, T. Developing and applying a GIS-assisted approach to locating wind farms in the UK. Renew. Energy 2001, 24, 59-71.

10. Van Haaren, R.V.; Fthenakis, V. GIS-based wind farm site selection using spatial multi-criteria analysis (SMCA): Evaluating the case for New York State. Renew. Sustain. Energy Rev. 2011, 15, 3332-3340.

11. Janke, J.R. Multicriteria GIS modeling of wind and solar farms in Colorado. Renew. Energy 2010, 35, 2228-2234.

12. Van Hoesen, J.; Letendre, S. Evaluating potential renewable energy resources in Poultney, Vermont: A GIS-based approach to supporting rural community energy planning. Renew. Energy 2010, 35, 2114-2122.

13. Grassi, S.; Chokani, N.; Abhari, R.S. Large scale technical and economical assessment of wind energy potential with a GIS tool: Case study Iowa. Energy Policy 2012, 45, 73-85.

14. Yue, C.D.; Wang, S.S. GIS-based evaluation of multifarious local renewable energy sources: A case study of the Chigu area of southwestern Taiwan. Energy Policy 2006, 34, 730-742.

15. High Plains Regional Climate Center. Historical Climate Data Summaries. Available online: http://www.hprcc.unl.edu/data/historical/ (accessed on 3 February 2014).

16. National Renewable Energy Laboratory. Wind Energy Resource Atlas of the United States. Available online: http://rredc.nrel.gov/wind/pubs/atlas/ (accessed on 3 February 2014).

17. US Geological Survey. National Elevation Dataset. Available online: http://viewer.nationalmap.gov/ viewer/ (accessed on 3 February 2014).

18. Tegou, L.I.; Polatidis, H.; Haralambopoulos, D.A. Environmental management framework for wind farm siting: Methodology and case study. J. Environ. Manag. 2010, 91, 2134-2147.

19. National Renewable Energy Laboratory. Wind Data. Available online: http://www.nrel.gov/ gis/data_wind.html (accessed on 3 February 2014).

20. Nebraska Department of Natural Resources. Land Use Data. Available online: http://dnr.nebraska.gov/land-use-data (accessed on 3 February 2014).

21. US Census Bureau. TIGER Products. Available online: https://www.census.gov/geo/maps-data/ data/tiger.html (accessed on 3 February 2014).

22. US Fish and Wildlife Service. USFWS National GIS Data. Available online: http://www.fws.gov/ gis/data/national/index.html\#NWI (accessed on 3 February 2014).

23. Jenks, G.F. The data model concept in statistical mapping. Int. Yearb. Cartogr. 1967, 7, 186-190.

24. Christidis, T.; Law, J. Mapping Ontario's wind turbines: Challenges and limitations. ISPRS Int. J. Geo-Inf. 2013, 2, 1092-1105.

(C) 2014 by the authors; licensee MDPI, Basel, Switzerland. This article is an open access article distributed under the terms and conditions of the Creative Commons Attribution license (http://creativecommons.org/licenses/by/3.0/). 